\title{
Front Matter: Volume 11646
}

, "Front Matter: Volume 11646," Proc. SPIE 11646, Polarized Light and Optical Angular Momentum for Biomedical Diagnostics, 1164601 (6 April 2021); doi: 10.1117/12.2596561

SPIE. Event: SPIE BiOS, 2021, Online Only 


\title{
Polarized Light and Optical Angular Momentum for Biomedical Diagnostics
}

\author{
Jessica C. Ramella-Roman \\ Hui Ma \\ Tatiana Novikova \\ Daniel S. Elson \\ I. Alex Vitkin \\ Editors
}

6-11 March 2021

Online Only, United States

Sponsored and Published by

SPIE 
The papers in this volume were part of the technical conference cited on the cover and title page. Papers were selected and subject to review by the editors and conference program committee. Some conference presentations may not be available for publication. Additional papers and presentation recordings may be available online in the SPIE Digital Library at SPIEDigitalLibrary.org.

The papers reflect the work and thoughts of the authors and are published herein as submitted. The publisher is not responsible for the validity of the information or for any outcomes resulting from reliance thereon.

Please use the following format to cite material from these proceedings:

Author(s), "Title of Paper," in Polarized Light and Optical Angular Momentum for Biomedical Diagnostics, edited by Jessica C. Ramella-Roman, Hui Ma, Tatiana Novikova, Daniel S. Elson, I. Alex Vitkin, Proceedings of SPIE Vol. 11646 (SPIE, Bellingham, WA, 2021) Seven-digit Article CID Number.

ISSN: 1605-7422

ISSN: 2410-9045 (electronic)

ISBN: 9781510641273

ISBN: 9781510641280 (electronic)

Published by

SPIE

P.O. Box 10, Bellingham, Washington 98227-0010 USA

Telephone +1 3606763290 (Pacific Time) · Fax +1 3606471445

SPIE.org

Copyright (c) 2021, Society of Photo-Optical Instrumentation Engineers.

Copying of material in this book for internal or personal use, or for the internal or personal use of specific clients, beyond the fair use provisions granted by the U.S. Copyright Law is authorized by SPIE subject to payment of copying fees. The Transactional Reporting Service base fee for this volume is $\$ 21.00$ per article (or portion thereof), which should be paid directly to the Copyright Clearance Center (CCC), 222 Rosewood Drive, Danvers, MA 01923. Payment may also be made electronically through CCC Online at copyright.com. Other copying for republication, resale, advertising or promotion, or any form of systematic or multiple reproduction of any material in this book is prohibited except with permission in writing from the publisher. The CCC fee code is 1605$7422 / 21 / \$ 21.00$.

Printed in the United States of America by Curran Associates, Inc., under license from SPIE.

Publication of record for individual papers is online in the SPIE Digital Library.

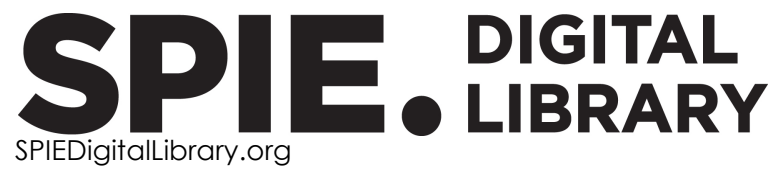

Paper Numbering: Proceedings of SPIE follow an e-First publication model. A unique citation identifier (CID) number is assigned to each article at the time of publication. Utilization of CIDs allows articles to be fully citable as soon as they are published online, and connects the same identifier to all online and print versions of the publication. SPIE uses a seven-digit CID article numbering system structured as follows:

- The first five digits correspond to the SPIE volume number.

- The last two digits indicate publication order within the volume using a Base 36 numbering system employing both numerals and letters. These two-number sets start with 00, 01, 02, 03, 04, $05,06,07,08,09,0 A, 0 B \ldots$ OZ, followed by 10-1Z, 20-2Z, etc. The CID Number appears on each page of the manuscript. 


\section{Contents}

PRE-CLINICAL APPLICATIONS OF POLARIMETRY

$116460 \mathrm{~A}$ A quantitative and non-contact technique to detect skin water content based on Mueller matrix polarimetry [11646-29]

$11646 \mathrm{OB}$ Comparison of anisotropic information using Mueller matrix imaging at different backscattering angles [11646-30]

OTHER APPLICATIONS AND INSTRUMENTATION

$11646 \mathrm{OF}$ Independent controlling of polarization states of two beams with different wavelengths [11646-24]

11646 OG Generation and detection of vector beams with geometric phase components and spatial light modulators [1 1646-25]

\section{ALGORITHMS AND COMPUTATIONAL APPROACHES}

11646 0l Depolarization in diffusely scattering media (Invited Paper) [1 1646-5]

$116460 \mathrm{~J}$ Polarized light reflectance and the sub-diffuse regime during optical imaging of skin [11646-6]

11646 OK Retrieving physical information of depolarizing systems [11646-7]

$11646 \mathrm{OL} \quad$ Mueller matrix orientation parameters unwrapping for statistically viable distribution [1 1646-8]

11646 OP Indices of polarimetric purity: application in biological tissues [11646-12]

MICROSCOPY

11646 OT Computational immunohistochemistry staining on lung tissues based on Mueller matrix microscopy [11646-21] 


\section{AI AND POLARIMETRY}

1164610 Single aerosol recognition based on deep learning of multidimensional polarization signals [11646-2]

1164611 Detecting cervical intraepithelial neoplasia using polarimetry parameters and multichannel convolutional neural network [1 1646-3]

POLARIZATION SENSITIVE TECHNIQUES

1164613 Pancreatic cancer collagen-based optical signatures [11646-16]

1164614 Symmetric decomposition of Mueller matrices reveals a new parametric space for polarimetric assistance in colon cancer histopathology [11646-31]

POSTER SESSION

1164615 Rapid Stokes imaging applied to monitor oscillations during optical tissue clearing [11646-38] 